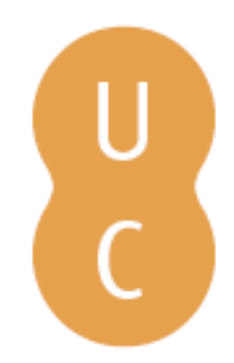

\title{
pompalina
}

\section{Trimalquião, os coronéis e a piscina: retrato impiedoso de um país em crise}

Autor(es): $\quad$ Mendes, António Manuel Gonçalves

Publicado por: Imprensa da Universidade de Coimbra

URL

persistente:

URI:http://hdl.handle.net/10316.2/37028

DOI:

DOI:http://dx.doi.org/10.14195/978-989-26-0548-7_8

Accessed : $\quad$ 26-Apr-2023 03:15:30

A navegação consulta e descarregamento dos títulos inseridos nas Bibliotecas Digitais UC Digitalis, UC Pombalina e UC Impactum, pressupõem a aceitação plena e sem reservas dos Termos e Condições de Uso destas Bibliotecas Digitais, disponíveis em https://digitalis.uc.pt/pt-pt/termos.

Conforme exposto nos referidos Termos e Condições de Uso, o descarregamento de títulos de acesso restrito requer uma licença válida de autorização devendo o utilizador aceder ao(s) documento(s) a partir de um endereço de IP da instituição detentora da supramencionada licença.

Ao utilizador é apenas permitido o descarregamento para uso pessoal, pelo que o emprego do(s) título(s) descarregado(s) para outro fim, designadamente comercial, carece de autorização do respetivo autor ou editor da obra.

Na medida em que todas as obras da UC Digitalis se encontram protegidas pelo Código do Direito de Autor e Direitos Conexos e demais legislação aplicável, toda a cópia, parcial ou total, deste documento, nos casos em que é legalmente admitida, deverá conter ou fazer-se acompanhar por este aviso. 
do Tempo e da História

- Mário de Carvalho e a reflexáo metaficcional sobre o futuro do romance - Sátiva e o cepticismo: configuração de personagens em Mário de Carvalho - Escrever tem arte e tem segredos... Era bom que trocássemos umas ideias sobre o assunto - O processo criativo em Era bom que trocássemos umas ideias sobre o assunto - Intertextualidade e metaficção em Fantasia para dois Coronéis e uma Piscina, de Mário de Carvalho - Trimalquiāo, os coronéis e a piscina: retrato impiedoso de um pais em crise $\bullet A$ Paixão do Conde de Fróis: paródia e subversão • "Como dizia o outro": a presença dos Clássicos em Mário de Carvalho - Cultura Clássica em Um

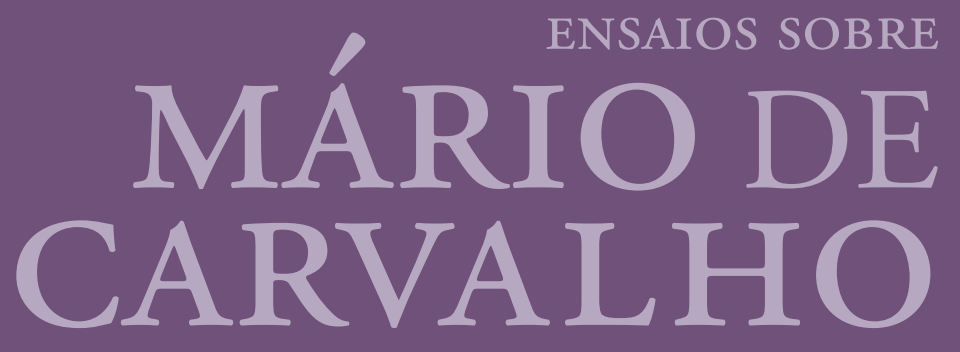

Maria de Fátima Silva Tereza Virgínia Ribeiro Barbosa COORD. IMPRENSA DA UNIVERSIDADE DE COIMBRA COIMBRA UNIVERSITY PRESS

elemento mouro como simbolo de alteridade $e$ barbárie em Um deus passeando pela brisa da 


\title{
Trimalquiáo, os coronéis e a piscina: retrato impiedoso de um país em crise
}

\author{
António Manuel Gonçalves Mendes \\ Universidade de Aveiro
}


(Página deixada propositadamente em branco) 
Com a publicação, em Novembro de 2003, do romance Fantasia para dois coronéis e uma piscina ${ }^{1}$, que tem merecido o melhor acolhimento por parte da crítica e do público ${ }^{2}$, Mário de Carvalho dá continuidade a "um opus dos mais consistentes da contemporaneidade" ${ }^{3}$, recuperando alguns tópicos e técnicas já revelados em obras anteriores, mas conferindo-lhe novidade, a começar pela designaçáo deste seu romance como um "cronovelema" (34), que o autor define como "uma narrativa que participa de vários géneros de escrita - novela, crónica, cinema e até poesia" ${ }^{\text {". Para }}$ além disso, este livro apresenta-se como um filme em forma de romance, em que a narrativa é apresentada numa sucessão de planos, sugerindo-se a movimentação de câmara, como se os vários espaços, tempos e personagens que desfilam nesta Fantasia estivessem a ser projectados num ecrã. Neste sentido, a escolha do título é tudo menos ingénua: por um lado, o romance vai sendo construído à imagem das composiçóes ou improvisos, mais ou menos livres de regras, a partir de um tema e suas variações, havendo várias referências musicais" à "simpática e deslumbrante Soraia Marina", ao "Rio Moldávia” de Smetana, entre outras; por outro lado, o vocábulo 'fantasia' remete, etimologicamente ${ }^{6}$, para a "aparição de coisas extraordinárias, que causam ilusão", anunciando o desenlace deste romance-filme, em que intervêm divindades, responsáveis pelo happy ending da história.

Num romance que se quer do século $\mathrm{xxI}^{7}$, o autor continua a dar asas à imaginação e criatividade, a lembrar um outro romance - $O$ Livro

* Este artigo corresponde, no essencial, ao publicado na revista Ágora. Estudos Clássicos em Debate (Aveiro, Universidade de Aveiro, 2005), dirigida por João Manuel Nunes Torrão.

1 Carvalho (Lisboa 2003). Todas as citaçôes serão feitas a partir desta edição.

2 Em Outubro de 2004, Mário de Carvalho obteve, com este romance, o Prémio de Novelística do Pen Clube Português, patrocinado pelo Instituto Português do Livro e das Bibliotecas.

3 Silvestre 1998: 213.

4 "Mário de Carvalho: crónica do aturdimento": JL - Jornal de Letras, Artes e Ideias 864, 12/11/2003, 12. Entrevista de Maria João Martins.

5 Morais e Silva 1953: s.u. 'fantasia'.

6 Machado 1995: s.u. 'fantasia'.

7 "É altura de começarmos a pensar no romance do século Xxi. E, como já não tenho a veleidade de matá-lo, acho que podemos prosseguir este caminho, no qual novas formas se ligam, se aglutinam e contribuem para dar objectos completamente diferentes. A verdade é que estamos impregnados de imagens, do cinema aos computadores e aos bonecos da Marvel”, afirma o autor. "Que raio de país é este?”: Visão 561, 04/10/2003, 174-178. Entrevista de Sara Belo Luís. 
Grande de Tebas, Navio e Mariana -: rompe com diversas convençóes literárias, recriando fábulas, personagens e ambientes; recorre a múltiplos estilos narrativos, que faz situar em diferentes tempos históricos e em outras esferas, e a peculiares relaçóes paródicas e intertextuais, que se manifestam nas citaçóes e nas frases recorrentes, e serve-se da inter-venção irónica de um narrador de feição camiliana ${ }^{8}$, com o objectivo de traçar um retrato impiedoso de um país em crise política, económica e social. A função do escritor, um pouco à imagem do teatro vicentino, é divertir o leitor, através da ironia subtil, e denunciar a vulgaridade e o prosaísmo do tempo desencantado em que vivemos, procurando "endireitar o mundo"?.

Como instrumentos poderosos que proporcionam histórias divertidas e que podem desencadear o riso, Mário de Carvalho lança mão de dois recursos: a já referida ironia e a paródia. Termo de difícil definição, a 'paródia'10 tem sido alvo de inúmeras abordagens e tentativas de descrição. Definido por Linda Hutcheon como "inversão irónica", "repetição com distância crítica que marca a diferença em vez de semelhança" ", ou "irónica "transcontextualização" e inversão, repetição com diferença"12, a paródia não é uma categoria única na literatura que se convencionou chamar de pós-moderna, pois é localizável em muitos textos das literaturas grega e latina ou na literatura trovadoresca, tendo chegado até nós através da literatura moderna ${ }^{13}$. Na prática, isto significa que o conceito de paródia tem sofrido alteraçóes ao longo do tempo. Entendida no âmbito literário, a paródia é vista por L. Hutcheon, que segue Genette, "como uma relação formal ou estrutural entre dois textos"14, o que, para muitos estudiosos, equivale a dizer que se está no domínio da intertextualidade. No entanto,

8 Melanda 2001: 38. Dissertação de Mestrado em Estudos Portugueses, apresentada à Universidade de Aveiro. Exemplar em CDRom.

9 Mário de Carvalho: "Pátria Lusitana - O retrato, a ironia e o desencanto": Os Meus Livros 19, 02/03/2004, 43. Entrevista de Cândido Oliveira Martins.

10 Vide Ferreira 2003: 279-300, onde o autor apresenta um erudito artigo sobre as várias definiçốes e teorias em torno deste conceito. Consulte-se também a introdução a este volume da autoria de Miguel Mora (2003) 7-13, onde, de forma simples e clara, se define o que é a 'sátira', a 'paródia' e a 'caricatura'. Veja-se, ainda, Ferreira 1999: 113-137 e 2000.

11 Hutcheon 1989: 17.

12 Hutcheon 1989: 48.

13 Melanda 2001: 90-91.

14 Hutcheon 1989: 34. 
na transcontextualização "está implícita uma distanciação crítica entre o texto em fundo a ser parodiado e a nova obra que incorpora, distância geralmente assinalada pela ironia” ${ }^{15}$. Ora, isso implica falar do cómico, do humor que a paródia sempre deve incluir. Hutcheon, na linha de Martin $\mathrm{Kuester}^{16}$, refere que à paródia não tem de obrigatoriamente corresponder o cómico. No entanto, como refere P.S. Ferreira, "ainda que, enquanto termo técnico musical, a paródia tivesse um ethos sério, a verdade é que, na acepção da paródia literária, o termo aparece quase sempre associado ao cómico"17. Focando o nosso olhar no autor que está na base deste estudo, concluímos que a paródia, em Mário de Carvalho, não abdica da distanciação irónica permitida pelo riso ${ }^{18}$. Como o próprio escritor refere, "o humorismo é a forma mais, não sei se diga mais eficaz, mas é com certeza a mais próxima de exprimir o desencanto"19. Assim, a única saída possível perante a sensação geral de desencanto é a ironia, a única forma possível de seriedade ${ }^{20}$.

Nas páginas que se seguem, procuraremos vislumbrar em que medida a referência a outros textos e autores pode ser veículo de humor, procurando identificar as suas implicaçóes, sob o ponto de vista ideológico, para o entendimento da obra.

\section{Em busca da autenticidade perdida}

O romance é uma singular viagem por um país tagarela, falador, que ninguém consegue calar (ao telemóvel, nas esquinas, nos jornais, nas televisôes), mergulhado numa profunda crise social e económica, e que se refugia, com frequência, em assuntos menores, em busca de uma autoestima colectiva. O falatório é geral, de norte a sul, atingindo todas as classes e profissões e "é causa de inúmeros despautérios, frouxas produtividades e

15 Hutcheon 1989: 48.

16 We should note again that the fact that there is a semantic element accompanying the structural changes does not imply that these changes have to be in the direction of humorous or comic effect. Kuester 1992: 7.

17 Ferrreira 2003: 296.

18 Cf. Melanda 2001: 90, nota 51.

19 Cotrim 1996: 45.

20 Hutcheon 1988: 39: "In fact irony may be the only way we can be serious today". 
más-criaçōes" (11). Para esta verborreia colectiva muito têm contribuído os telemóveis, para muitos, a melhor invenção dos últimos tempos!

O país não tem nada a dizer, a ensinar, a comunicar. O país quer é aturdir-se. E a tagarelice é o meio de aturdimento mais à mão (11).

É neste contexto que surgem dois coronéis que resolvem, por diferentes razóes, deixar Lisboa e fixar-se no Alentejo. Um chama-se Bernardes e dorme com uma metralhadora $U z i$ debaixo da almofada; o outro tem por nome Lencastre, nasceu em Goa e tem um filho, o Nelson, que gosta de pintar todas as paredes brancas com tags e grafitis. Ambos são casados. Maria das Dores é a mulher de Bernardes, é de famílias ricas, teve uma educaçáo selecta que não "jogava" nada bem com a linguagem vernácula que utilizava, estando a preparar uma tese de mestrado na Universidade de Évora, intitulada "O traje feminino entre os Povos originários da Lusitânia Tarragonense”. Maria José é a esposa de Lencastre, gosta de agricultura e de decoração. O coronel Bernardes, na sequência de um mau jeito nas costas, lembrou-se de construir uma piscina. Lencastre, para fugir ao filho, decidiu viver perto de Bernardes. Para além de serem militares, o que os une verdadeiramente é o ódio ao país tagarela.

Para a construção da piscina é preciso haver água. Emanuel Elói é um jovem vedor, racional, bondoso e mestre de xadrez, contratado por Bernardes para desencantar lençóis freáticos no seu monte, junto de Serpa. Emanuel, por sua vez, tem um tio virtual que aparece sem avisar, a despropósito, e que tenta corromper o narrador, para que este náo maltrate o sobrinho durante o romance.

O coronel Bernardes, como referimos, decidiu rumar ao Alentejo "numa atitude de protesto" (25) em relação aos vizinhos do prédio, que decidiram pôr em causa a sua administração do "condomínio da Rua de Santo Estêvão à Lapa" (28). Dores incentivou-o a abandonar o cargo, antes de ser demitido. Juntou-se assim o útil ao agradável:

Ala para o Alentejo, para os grandes espaços, o apartamento de Lisboa ficava para as excepçóes. Antes a rústica simplicidade que o contacto com a melíflua e falsa gente que não prestava preito à competência de mando de um cidadáo que passara a vida a dar provas (31). 
Há, neste exílio ${ }^{21}$ do coronel, perante o vexame de quem sente a sua autoridade posta em causa, o desejo de voltar para uma autenticidade perdida, de contactar com a Natureza:

Mal se haviam instalado, o coronel Bernardes começou por entoar loas a tudo o que descortinava ao redor, o humilde alecrim, a melancolia dos rebanhos, a vida simples e filósofa dos pastores, os ritmos retardados das horas, a fauna, que bom, a flora, que bonita, os nativos, que gente (32).

Este topos da procura do campo como resultado do cansaço da cidade tem tanto de contemporâneo como de antigo. Lembremos o Rato do Campo da famosa fábula de Horácio ${ }^{22}$, que só aprecia os bens que possui quando experimenta a sua ausência. Portanto, só a partir da cidade se pode desejar o campo. Já na cultura helenística, este sentimento aparecia de modo intenso: o melhor exemplo talvez seja a poesia bucólica que teve como impulsionador Teócrito, um grego que tinha nascido numa megalópole, Siracusa. Nos seus Idílios mostra-se o gosto pelos ambientes e personagens rústicas, ao mesmo tempo que se procede à exaltação da paisagem.

Virgílio, numa temática estritamente pastoril, compôs as Bucólicas, onde se contempla a paisagem campestre, a silua, com uma nostalgia e devoção mais intensas. Um exemplo evidente desse desejo do campo e da repulsa da cidade está nas palavras de Córidon ${ }^{23}$ :

21 Usamos o termo 'exílio' por sugestão do próprio narrador, que antes referira: "Agora importa reflectir a relaçâo historicamente comprovada entre o vexame e o exílio. Nâo faltam os casos em que um elevado conceito de honra ou dignidade leva a recusar a sombra, em vida, e os ossos em morte, às pátrias. A escala deste coronel era, convenhamos, mais modesta. Não chegava à dimensão de toda a Pátria” (31). Os coronéis Bernardes e Lencastre procuram o campo não tanto pelo otium mas para, à volta da piscina, comentarem os problemas do país com "uma visão distanciada e lúcida" ("Mário de Carvalho - Crónica do aturdimento”: $J L, 12 / 11 / 2003,11)$. Dá-se, assim, “a substituição do otium pelo exílio, ou seja, da estabilidade emotiva e da serenidade arcádica pela problematizaçáo e pela angustiante sensação de queda", como refere Cardoso Bernardes 1988: 20, nota 2 .

22 Horácio, Sátira 2, 6. Veja-se a este propósito o artigo de Cristóbal (1992) 131-143.

23 Virgílio, Bucólicas 2, 61-62. A tradução é de Mendes 1997: 194-5. 
... Pallas, quas condidit arces

ipsa colat; nobis placeant ante omnia siluae.

... More a própria Palas nas cidadelas que

fundou; a nós agradem-nos os bosques, acima de tudo.

A própria filosofia antiga enaltecia a qualidade de vida no campo. Os estóicos defendiam uma existência natural e selvagem e repudiavam todo o artifício da civilização. Para os discípulos de Epicuro, o campo era o local ideal de vida para o sábio. E uns e outros louvavam as vantagens de uma vida retirada.

Em suma, a literatura, espelho de mitos e realidades, sempre testemunhou esse desejo humano pela Natureza. Hoje, ao mesmo tempo que o homem pensa na natureza como cenário de liberdade, teme pela sua destruição e inquieta-se com a preservação do meio ambiente. Por isso, ao decidir construir uma piscina no monte alentejano, o coronel Bernardes atenta contra esse locus amoenus, impondo àquele espaço natural, algo de extremamente artificial:

Lá em baixo, na paisagem, incrustada na duríssima permanência das coisas, onde só mandam altos castelos, menires e cromeleques, destoa azulínea, e sobressalta, com a transparência, a piscina, modernaça e tratada a poder de fluidos caros e especiosos (19).

Apesar disso, o narrador alega o seguinte em defesa dos coronéis:

... é justo arguir que eles náo guardam arames entre as ramagens das árvores, não deixam sacos de adubo ao vento, não abandonam velhas máquinas e engrenagens na charneca, náo largam entulhos nas carreteiras, não matam abetardas e outras aves protegidas, não envenenam faunas predadoras, não cortam chaparros para lenha, não plantam eucaliptos e mimosas, não ateiam queimadas em Agosto, não atiram para o cháo cascas de melancia, não se esquivam aos impostos, não intrujam nos negócios e, de uma forma geral, separam os lixos, isolam as pilhas, ensacam o conjunto e, com regularidade, acabam por deixar tudo no contentor camarário mais próximo... (20).

É óbvia a simpatia do narrador para com os coronéis. Ao contrário da maioria dos seus concidadãos, eles náo atentam contra a Natureza nem contra o meio ambiente, cumprem os seus deveres de cidadania e não prejudicam os semelhantes. 


\section{O paradigma do novo-rico}

Construir uma piscina, porém, implica ter posses. No caso de Bernardes a sua construção começou por ser uma necessidade. É certo que sempre poderia deslocar-se à piscina de Serpa, como lhe sugeriu a Dores (64). No entanto, o Coronel, tal como os senhores da Roma Imperial, que possuíam, nas suas uillae, balneários privativos, rende-se à evidência de que a "hidroterapia é que está a dar" - como leu no subtítulo de um jornal -, mas nada de se deslocar a Serpa: a piscina "queria-se era ali, em pleno campo, privativa, ao dispor, alumiada e amornada pelo valente sol alentejano...” (64). E dá-se início à construção. A cratera estava já aberta e foi alvo de uma visita nocturna, por parte do coronel. Por momentos, sentiu-se um latifundiário, dono de um bom pedaço de terra, se escavasse sempre até ao centro da terra. Ao olhar para o céu negro "confrontou-se com a ideia de que também era proprietário de todo o espaço sobrejacente até Plutão, até aos confins do Universo" (125).

O coronel nunca tinha lido Petrónio, porque o romano nunca se ocupou de coisas militares, e naquele instante em que contemplava a grandeza quase infinita dos seus domínios não podia saber que um tal Trimalquião já tinha procedido a um raciocínio aparentado, mas na horizontal, à uma, por se encontrar deitado, à outra, por considerar apenas o caminho terrestre entre Roma e África" (125).

O passo do Satyricon a que se alude é conhecido (37.8):

Ipse Trimalchio fundos habet, qua milui uolant, nummorum nummos. Argentum in ostiarii illius cella plus iacet, quam quisquam in fortunis habet.

Quanto a Trimalquião, tem propriedades por onde os milhafres podem espraiar o voo, rios e rios de dinheiro. Há mais prata pelo chão do quarto do seu porteiro que muita boa gente tem no seu património. ${ }^{24}$

Trimalquião é o protagonista de um episódio famoso e único: a Cena Trimalchionis. É um liberto cuja riqueza é imensa e, ao longo da cena, há muitos pormenores que nos dáo conta dessa realidade. Este fragmento faz parte do retrato feito por Hérmeros, o qual denota uma certa admiração

24 Seguimos a tradução de Leão (1998) 100. 
pelo sucesso conseguido pelo novo-rico, em boa parte devido ao dinheiro que a sua capacidade empreendedora realizara e que podemos ler nas suas próprias palavras:

Quicquid tangebam, crescebat tanquam fauus (76.8)

Coisa em que eu pusesse as mãos, medrava que nem favo de mel $^{25}$

A referência ao voo dos milhafres é proverbial. O milhafre, voando alto no céu e com uma vista penetrante, é observado pelos augúrios nas evoluçôes significativas, e normalmente ligado a Apolo como símbolo de clarividência ${ }^{26}$. Neste sentido, apesar dos pensamentos de Bernardes aparentarem tiques de novo-rico ${ }^{27}$, à maneira de Trimalquiáo, eles denotam antes de mais a clarividência de alguém que sendo militar na reforma, se sente investido de autoridade para poder comentar, na companhia de Lencastre, as venturas e desventuras das personagens da actualidade, seus vícios e atitudes, muitas delas merecedoras de reprovação. A piscina é um local agradável e simbólico, à volta do qual se fazem essas conversas. É como se ela deixasse de servir para as funções que lhe estão destinadas e passasse a ser apenas o pretexto para o encontro e conversa dos coronéis. A piscina, até pelo formato rectangular, simboliza Portugal, a um tempo local e assunto de conversa.

Nunca aqueles dois deram um mergulho camarada na piscina. Uma única vez tinha ela sido usada pelo coronel Bernardes e por Maria das Dores. Fora no dia da inauguração, com Felismina a presenciar, sem ter muito a certeza de que estava de acordo com aquilo (149).

Embora a gozar de boas reformas e com uma vida confortável, os coronéis mais do que corresponder ao paradigma do novo-rico, têm a função de apreciar as atitudes de personagens como Januário. Oriundo "duma daquelas terras do Norte com o nome acabado em 'elo', ou 'oso', ou 'ais'”, (188), Januário, o pai de Sandra, encarna aqui o verdadeiro paradigma do

25 Leão 1998: 103.

26 Chevalier, e Gheerbrant 1994. Tradução portuguesa de Cristina Rodriguez e Artur Guerra, s.u. 'milhafre'.

27 Convém lembrar que o coronel Bernardes é um antigo capitão de Abril, militante de esquerda durante o PREC, que acabou por casar com a filha de um latifundiário e ter uma vida confortável, passada entre o condomínio fechado de Lisboa e a piscina no Alentejo. 
novo-rico. Tendo feito uma comissão em África, enriqueceu à custa de negócios pouco claros, entre os quais a exploração de imigrantes ilegais. Revela, por isso, alguns dos traços distintivos que caracterizam o novo-rico: a ostentação das riquezas (o automóvel Saab, uma vivenda que se destaca das outras); a gabarolice ("Diz que tem uma casa com quatro elevadores e uma arca frigorífica sempre a abarrotar de marisco", 189); a arrogância e a prepotência ("Aliás, comigo ninguém faz farinha, ouviu?", 58); a linguagem vulgar e grosseira, nomeadamente quando joga uma partida de xadrez com Emanuel ("Mas que merda é esta? Falamos chinês, ou o caraças?", 59); o excesso de comida e de bebida ("enchia de uísque um grande copo de conhaque e atirava-se a uma pratada de gambas", 57); e a parolice, na maneira como se veste ("blaser preto, com botóes redondos de lata dourada, calça amarelo-torrado, e camisa cor-de-rosa”, 52). Todos estes traços evidenciam o contraste entre a ostentaçáo de poder e a figura caricata da pessoa que a motiva ${ }^{28}$.

\section{A paródia da epopeia}

Para além da semelhança de pensamentos entre o Coronel e Trimalquião, outros paralelismos podem ser estabelecidos entre as duas histórias e respectivas personagens. Entre a época de Nero e a actualidade há um grande hiato temporal, mas a uni-las está uma profunda crise social, com as instituiçóes a perderem credibilidade e autoridade. Tal como no romance de Petrónio, em Fantasia para dois Coronéis e uma piscina, os heróis, ou anti-heróis, andam constantemente em busca de dinheiro e de aventuras de amor ${ }^{29}$. Façamos um breve elenco das personagens e comecemos pelas masculinas:

A personagem principal é um jovem alto, veste ganga azul, um pólo claro, cor de burro quando foge, e os cabelos, nem curtos nem compridos, foram desamigados de pente há muito tempo (14). "É daquelas figuras que inspira simpatia e confiança a um primeiro olhar, mesmo de longe. Chamase Emanuel Elói, é uma bondade de moço, trotamundos, e tem algum jeito e muita paciência para os seus conterrâneos" (14). O pai quis dar-lhe "um nome benigno e abençoado e fez uma lista de que constavam os seguintes: «Eloim, Adonai, Sadai, Soter, Emanuel, Sabahot, Tetragrammaron, Alpha

28 Vejam-se a este propósito os trabalhos de Leão 1996: 161-182; (1997) 147-167; e 2004: 191-208.

29 Cf. Medeiros 1997: 171. 
et Omega, Principium et Finis, Hagios, Ischiros, Otheos, Athanatos, Agla, Jehova, Homonsion, Ya, Iesus Christós, Messias, Elva, Elrei...» Mas o empregado do Registo Civil só aceitou Emanuel” (67). É também uma personagem da simpatia do narrador, um verdadeiro "deus connosco"30, que apesar de andar numa atitude constante de procura de realização, de felicidade, no seu Renault Quatro, trilhando os caminhos de norte a sul ${ }^{31}$, é o único que o faz de forma desinteressada, tendo atitudes de altruísmo como quando dá boleia ao apicultor Eleutério ${ }^{32}$. Este, por seu turno, pretende, com vinte litros de mel, realizar "a bela maquia de mil cento e noventa euros"(12), tendo destinado uma parte para comprar uma prenda para Irina, "porque as namoradas em pousio desertam" (12). Um pastor, sem nome, consegue uma indemnização de 100 euros de Bernardes ao simular um ferimento com molho de tomate na lã de um borrego (38-42). Nunes Norberto, o Nónó, está em Caxias, porque tirava músicas da net e "distribuía-as, a um preço simbólico" (50). Januário foi furriel, tem 50 anos, é presidente do clube de bola, vereador da câmara, sócio honorário dos bombeiros, tem uma padaria, uma fábrica de louças, três oficinas de automóveis, quatro lojas de electrodomésticos, duas casas de alterne, um bar e um bordel clandestino. Tem uma mansão com dois elevadores, como empregada uma imigrante russa, Natacha, que trabalhava num estabelecimento nocturno ${ }^{33}(52,188)$. O Tio do Emanuel, "monárquico,

30 Cf. Is 7,14: "Por isso, o mesmo Senhor por sua conta e risco, vos dará um sinal: olhai: A jovem está grávida e dará um filho, pôr-lhe-á o nome de Emanuel” (A citação da Bíblia é feita segundo a $8^{\circ}$ edição da Difusora Bíblica, editada em Lisboa, em 1978.

31 Como nos lembra Paula Melanda, "não é por acaso que a estrutura básica da acção nas diversas sequências narrativas de O Livro Grande de Tebas, Navio e Mariana e de outros livros de Mário de Carvalho, assenta em metáforas da progressão, tais como a viagem e a busca; encontros que tomam a forma de diálogos, de combates, de situaçóes de cerco e fuga..." (Cf. Martins (Lisboa 1983) 186-187). O Renault Quatro é o meio que permite a Emanuel Elói essa procura "que visa o encontro de uma pátria desimpedida, capaz de preencher o vazio deixado pela amputação que marcaria o pós-revolução; é em suma a demanda de uma pátria a que se possa chamar 'Pátria”" (Melanda 2001: 120-122).

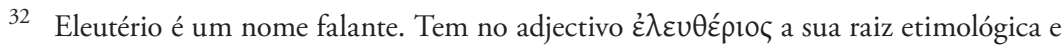
significa 'o que fala ou procede livremente; que tem sentimentos de um homem livre'. Remete-se, portanto, para a liberdade ( $\dot{\lambda} \varepsilon \cup \theta \varepsilon \rho i ́ \alpha)$ conseguida com o 25 de Abril, contudo, nem sempre exemplarmente vivida, simbolizada na cena em que Eleutério e Desidério, aquando das escavaçôes para a piscina, atentam contra o património arqueológico encontrado (ânforas e um mosaico), possuídos por um desejo (desiderium) desenfreado de enriquecer: "Estavam convencidos de que as ânforas poderiam estar cheias de moedas" (128).

33 Januário revela-se uma autêntica 'porta' (ianua) de entrada para a mão de obra estrangeira. O nome próprio é a transcrição do substantivo latino Ianuarius, que dá o nome ao mês da passagem de um ano a outro, 'Janeiro'. Etimologicamente liga-se a Ianus, 
extravagante, mulherengo" (66), é adepto da técnica da triangulação, isto é, $\mathrm{a}$ arte de bem se relacionar com quatro mulheres ao mesmo tempo. "A primeira, ad quem, não conta, porque é a que desfecha a situação. Não faz parte do triângulo: obriga ao triângulo" (167). Afonso Tovar, fuzileiro, envolveu-se com uma garota, a Filipa, empregada bancária. Primeiro foi viver com ela, depois "envolveu-se à porrada com um ex-namorado dela e foi parar ao banco do hospital, com vários pontos" (187).

Se os homens não são heróis, não se espere algo diferente das mulheres. Destaca-se, pela positiva, a esposa do coronel Lencastre, Maria José, "prendada moça, de linhagem militar" (72), tem atitudes carinhosas para com o marido e revela compreensáo para com a rebeldia do filho Nelson. Pela negativa, por uma ou outra razão, destacam-se as restantes: Maria das Dores, esposa de Bernardes, procura aventuras; sente-se fortemente atraída por Emanuel, desde que o vê pela primeira vez, a ponto de se meter na sua cama, no fim da história. Mantém uma relação com o Tio do Emanuel, sendo uma das mulheres da triangulação. Irina é a "conversada" (36) do apicultor, imigrante de leste, sente também ela forte atracçáo pela personagem principal: passam a noite juntos "na penzan Rosmaninio" (38). Natacha é uma emigrante russa, trabalhava num estabelecimento nocturno, agora é criada de servir em casa de Januário. Sandra tem um Smart, foge com Emanuel na noite em que este estivera a jogar uma partida de xadrez com o pai dela. Passam a noite juntos. Angelina, empregada do bar da estação de serviço, estava a namoriscar com o segurança, quando aparece Emanuel. Com a chegada da claque dos adeptos de futebol e iminente destruição da loja de conveniência, atrela-se a Emanuel, fazem amor no Renault Quatro e, no fim, cobra-lhe 50 euros. Tia Felismina, empregada doméstica do casal Bernardes, reclama o seu quinhão numa eventual partilha de moedas, que supostamente estariam nas ânforas, descobertas por Desidério e Eleutério. Filipa, empregada bancária, alimenta a paixão por Afonso Tovar.

Um olhar atento sobre algumas destas personagens permite-nos concluir que, tal como no Satyricon, há uma crise dos paradigmas tradicionais: os mais velhos, "em tempos de indefiniçáo, devem funcionar como guia e baluarte do bom gosto e de uma conduta apropriada"34. Isso, porém, não

'Jano', um dos mais antigos deuses do panteão romano, representado por dois rostos que se opóem. Atribuem-se ao seu reinado as características da Idade de Ouro: a honestidade dos homens, a abundância, a paz profunda, situadas nos antípodas das características reveladas por Januário. Consultem-se Grimal e F. Martin, s.u. 'janus'.

34 Leão $2004^{\mathrm{a}}$ : 233-234. 
acontece no romance: Maria das Dores, traindo o coronel, deseja o jovem Emanuel; o Tio deste dá instrução ao sobrinho no âmbito da triangulação; a Tia Felismina revela a mesma ambição pelo lucro fácil, como os jovens Eleutério e Desidério; o pastor, sem nome, simula um ferimento num animal para conseguir uma indemnização de 100 euros do coronel. Os mais velhos não são mais os heróis, nem os modelos para as geraçôes mais novas.

Estas personagens, espelho da vulgaridade que caracteriza o quotidiano, e os pormenores realistas com que nos são apresentadas mostram o prosaísmo do mundo desencantado em que vivem. $\mathrm{O}$ narrador, porém, à boa maneira clássica, invoca a sua musa inspiradora:

... gentil Polímnia, grácil musa que por mim zela, e que não rejeito invocar... (17)

Musa excelente e demais luzidas divindades... (20)

Nô mais, ficção, nô mais! Desce tu, Musa, a de sorriso loução... (227)

$\mathrm{O}$ assunto do romance não é, como já vimos, elevado, não canta os feitos sublimes de um herói ou heróis. A invocação da musa Polímnia ${ }^{35}$ só pode ter aqui um efeito paródico. Com efeito, o heroísmo, que é adequado na epopeia ${ }^{36}$, é posto a ridículo por uma narrativa que só para o parodiar o convoca. Podemos afirmar com Marie-Heléne Robilliard que "o autor, historiógrafo desenganado, escreve uma História que está nos antípodas da epopeia, opondo ao sentido da epopeia uma sensação de absurdo, à glorificação do heroísmo a sua paródia e ao fresco histórico a história de pessoas simples e anónimas" ${ }^{37}$.

Estas pessoas simples e anónimas, na era da comunicação, que utilizam o telemóvel descontroladamente, revelam, paradoxalmente, dificuldades em comunicar. E, como se sabe, incomunicabilidade gera desencontro. Ao nível das relaçóes familiares, o desencontro fica bem patente nas relaçóes entre pais e filhos, paradigma do tradicional conflito de geraçóes. Exemplo

35 Polímnia é uma das nove Musas, filhas de Zeus e de Mnemósine. Segundo a tradição, teria inventado a lira e descoberto a agricultura. Vide Grimal, s.u. 'Polímnia'.

36 Num outro passo, faz-se alusão a uma das epopeias clássicas: "Daí a umas horas, vinha perto a manhã, já toava a orla do céu a aurora de róseos dedos" (p.61). Cf. Odisseia 2.1 "Quando surgiu a que cedo desponta, a Aurora de róseos dedos..." Homero, Odisseia (Lisboa 2003), tradução de Frederico Lourenço.

37 Robilliard 2002: 96. 
disso é o relacionamento entre o coronel Lencastre e o seu filho Nelson: quando se encontram, desconversam (o que é já de si uma negação da conversa), mantêm falsos diálogos, para não dizer monólogos, como aquele em que Nelson, depois de ter falado sozinho, é agredido fisicamente pelo pai e expulso de casa (73-75). Algum tempo depois, as saudades levam Nelson a questionar-se: "Mas porque raio é que o velho não usa telemóvel?" (167).

A comunicação entre marido e esposa é outra dificuldade. Também a este nível há desencontros. $\mathrm{Na}$ obra, estão bem documentadas as relaçóes conflituais dos homens e das mulheres desta geração, tal o número de situaçôes de infidelidade e de traição descritas, que atingem todas as personagens, das mais às menos relevantes: Irina troca Eleutério por Emanuel; Angelina troca o segurança por Emanuel; Afonso Marinheiro troca a esposa Madalena por Filipa; Lopes Geraldo troca a mulher por outra; um alentejano, a fazer uma comissão em África, é informado da traição da mulher pelos seus familiares; e Dores acumula Bernardes com Emanuel e o Tio deste - "Gosto de coleccionar. Sou aditiva. E depois?" (185).

Este assunto alimenta as conversas dos coronéis. Eles sabem que tanto se pode ser vítima de traição como se sentir impelido para trair.

Em suma, um gajo, pá, tem de se rodear de todas as cautelas. «Se não fores casto, sê cauto ${ }^{38}$, como dizia o outro (193).

Bernardes era vítima de traição e ele sabia. O que ele não queria acreditar era que Dores o tentasse trair mais uma vez, na sua própria casa, com o hóspede Emanuel. $\mathrm{O}$ narrador anuncia o adensar trágico, fazendo ecoar Horácio ${ }^{39}$ :

38 Tosi (2000) 700, referencia esta máxima na sua correspondente latina Si non caste, saltim caute, dizendo que ela é de origem desconhecida. Para além da paronomásia caste / caute, importa salientar que castus tem, em latim, um significado mais amplo do que o nosso casto, pelo que, originariamente, a sentença não se restringiria apenas à prudência necessária com os amores furtivos. Os provérbios, os adágios, as máximas, enquanto fragmentos de narrativas ancestrais, são usadas pelos coronéis como síntese da sua experiência e apresentadas para proveito e exemplo (prodesse et delectare) dos leitores. Cf. Melanda 2001: 132-133.

39 Horácio, Ode 1.11.7-8: Dum loquimur, fugerit inuida aetas. Esta expressão da celebérrima ode do Venusino anuncia o sintagma já tantas vezes citado: Carpe diem. Nesta ode, o poeta começa por advertir Leucónoe ('espírito branco') a não sondar o futuro, pois "sofrer" o futuro é, antes de mais, estar presente para o viver (cf. Tony dos Santos Ferreira (1990), "Carpe diem - Breves pensamentos de um pensamento breve" Boletim de Estudos Clássicos 13: 154). Ironicamente, o coronel Bernardes, neste passo, é semelhante a Leucónoe, 
Mas as horas transcorrem, todas ferem, a última mata, e, enquanto falamos, eis que o invejoso tempo foge (216).

A responsabilidade dos desencontros entre homem e mulher é, inevitavelmente, das mulheres. É esta a posição misógina do Tio de Emanuel. As longas esperas a que ele tem estado sujeito, os "esforços, tédios, cansaços, desânimos e vexames" (89), que ele tem suportado em nome da sedução deixam-no amargurado. Enumera depois uma série de situaçóes, algumas das quais se encaixam nos caracteres femininos descritos por Semónides de Amorgos ${ }^{40}$, num fragmento ímpar da poesia arcaica grega, em que o poeta oferece uma reflexão sobre a natureza feminina. Estas queixas, porém, não devem levar o seu sobrinho à desistência:

Eu quando enumerei as dificuldades e complicaçôes que há no trato com as mulheres estava a preparar-te para a vida. Para não desistires à primeira e aguentares a pé firme. (...) Enunciei uma tipologia, aliás bastante incompleta. Admito - isto um tipo, após os gregos antigos, tem a obrigação de ser justo - que do lado delas existam tipologias equivalentes (160).

As razōes de queixa são antigas e, pelos vistos, são mútuas...

\section{Deus ex machina}

Neste ambiente "de desencanto, a marginalidade parece uma opçáo inevitável”»ł1. Nelson, Neusa e Tiago são, tal como Encólpio, Gíton, Ascilto, intelectuais vadios, uma espécie de hippies sempre disponíveis, que vivem de expedientes. É certo que os de Fantasia... não são tão perversos. Mas vivem no seu mundo, andam numa caravana, sem rumo, nem destino. Usam linguagem diferente, vestem-se e penteiam-se diferentemente, usam piercings, fumam droga, partilham a caravana, que tinha sido, inclusive, "comprada a meias" (162). Os temas de conversa, porém, fogem da vulgaridade: falam de artes, de cinema, "da amizade, lealdade e confiança entre

isto é, ingénuo, não na sua credulidade de conhecer o futuro, mas quanto à infidelidade tentada de Maria das Dores com o jovem vedor Emanuel.

$\begin{array}{ll}40 & \text { Brasete 2003: 39-56. } \\ 41 & \text { Medeiros 1997: } 172 .\end{array}$ 
as pessoas" (163). Deixam as suas marcas (tags) nos sinais de trânsito e nas paredes brancas, para afirmação da sua diferença. Sobrevivem de trabalhos manufacturados - uma "bandeira portuguesa feita de caricas", um "CristoRei de caracóis" - e de contribuiçóes generosas, que a mãe de Nelson lhe dá, sem Lencastre saber. À margem do viver social, protestam passivamente contra a sociedade do seu tempo, demarcando-se da procura desenfreada do lucro fácil. A rejeição de Tiago por tudo o que de mau esta sociedade representa está bem patente no seu grito:

Geraçôes caducas, os gajos já cá deixaram o que tinham a deixar e nunca mais se vão embora. (159)

O desencanto poderia ser resolvido se o homem reencontrasse o caminho do divino ${ }^{42}$. Há, na obra, apariçóes de deuses que deixam entrever uma réstia de esperança contra o pessimismo. Emanuel é bafejado por essa presença. A primeira aparição dá-se quando a personagem principal se desloca a uma estação de serviço para atestar o depósito do Renault Quatro:

Uma estação de serviço, a salvação. Sem antecedentes nem provocaçáo, ocorreu a Emanuel aquela imagem dos sonhos, de um deus dependurado de uma grua que lhe aparecia de súbito em frente, a vociferar (103).

Uma outra aparição é razão para Emanuel dar boleia a um desconhecido, que por acaso era o seu Tio:

Mas duas razóes levaram o jovem Emanuel a trilhar os calços. A primeira é que, ao passar pelo castelo do Alvito, hoje apousadado, tinha distinguido, nos adarves duma torre, uma figura, desta vez feminina, de capacete parecido com o dos bombeiros, uma coruja ao ombro, muito resplandescente, a ponto de sobrepujar os holofotes da Câmara e que parecia ter sido ali depositada, no momento, por uma grua da construção civil (156).

As apariçóes repetidas, ora de um deus, ora de uma deusa, numa clara paródia à intervenção do deus ex machina, conferem ao romance essa dimensão de sonho, fantasia e humor, principalmente, quando se 'transpor-

42 Medeiros 1997: 172. 
tam' da cena do teatro clássico do século v a.C. as maquinarias teatrais, que contribuíam para o aumento da espectacularidade dos processos cénicos,

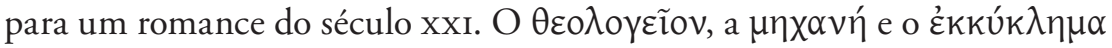
eram recursos cénicos utilizados pelo dramaturgo para as teofanias finais, isto é, para fazer aparecer um deus, em voo, no final da peça, com o intuito de repor a harmonia e a tranquilidade perdidas ${ }^{43}$.

Através da "figura que empunhava um arco de fantasia", o narrador, usando a auto-ironia, resgata o protagonista, Emanuel Elói, de uma situação desesperada: a fuga da casa do coronel Bernardes, depois de Dores, qual ninfomaníaca, ter solicitado os seus favores sexuais, exclusivamente para satisfação da sua libido (222). O 'Anjo da Guarda' de Emanuel não permitiu que ele perecesse na cena de perseguiçẫo final em que se dá o $h a-$ ppy ending: o coronel Bernardes, com a honra ofendida, varre tudo à volta com a metralhadora $U z i$, dando largas à sua autoridade; Emanuel é poupado; Nelson Lencastre, com a caravana, atraído pela luminosidade, aparece e reencontra-se com o pai "num amplo, pesado e terno abraço" (226).

Alargando o âmbito da interpretação, o aparecimento de um deus ex machina, numa scaena, onde tudo remete para a vulgaridade, justificase como sendo uma chamada de atenção ao homem, para a existência de outros valores. Emanuel é o único a quem os deuses aparecem, a ter atitudes de altruísmo para com os seus concidadãos, a revelar alguma indiferença pelos valores materiais, a usar a inteligência (e.g. jogo de xadrez).

$\mathrm{O}$ aparecimento de Atena ${ }^{44}$ sugere o uso da inteligência em detrimento da força, a defesa da civilização perante a barbárie. Atena usa a inteligência para os heróis ultrapassarem as piores dificuldades. Foi assim com Ulisses,

43 Deus ex machina é uma expressão latina, tradução da locução grega $\theta$ cò $\mu \eta \chi \propto \nu \tilde{\eta} \varsigma$, usada no âmbito teatral, nomeadamente por Eurípides (séc. v a.C), para designar o aparecimento de deuses e heróis suspensos num engenho ( $\mu \eta \chi \alpha \nu \eta ́)$, colocado à esquerda da cena, em plano elevado, com o intuito de resgatar prodigiosamente os protagonistas de alguma situação desesperada na parte final das peças de teatro. Para além da $\mu \eta \chi \alpha v \eta ́$, exis-

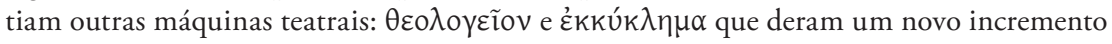
ao espectáculo teatral, aumentando a criatividade, a ponto de algumas peças de Eurípides, e.g. Andrómeda, Hércules Furioso (822 sqq., 872), Andrómaca 1226-1232), terem sido parodiadas por Aristófanes, por causa das suas novidades revolucionárias. O recurso à $\mu \eta \chi \propto v \eta ́$ e às teofanias finais nem sempre foi bem visto pelos antigos. Horácio, por exemplo, diz, a este propósito, nec deus intersit, nisi dignus uindice nodus / inciderit (De arte poetica, 191-2). Sobre a definição deste dispositivo e sua utilização consulte-se Silva 1987: 156-161 passim; Duncan 1935: 126-141; Schmidt 1963: 88-112; Dunn 1985: 111-167.

44 Sem nomear explicitamente a deusa Atena, o narrador fala apenas de "uma figura, desta vez feminina" e refere uma das suas insígnias: um "capacete parecido com o dos 
que regressa a casa depois da guerra de Tróia. Quanto a Emanuel "foi por a deusa ter indicado aquela estrada, de entre caminhos e direcçóes possíveis, que ele a escolheu" (156).

\section{5. "Falhou a Revolução?"}

Daqui decorre uma aposta na instrução e na cultura para fazer face a uma sociedade sem valores, rendida aos tiques do novo-riquismo, ao telelixo televisivo, à música pimba (que a cantora Soraia Marina tão bem personifica), que embrutece e que faz as delícias de um país inteiro, onde há bárbaras claques de futebol que destroem estaçôes de serviço.

É necessário mudar mentalidades, apostar na educação e no civismo. A voz da jovem Sandra reclama-o em tom de lamento: "Ainda há muita coisa a aperfeiçoar na nossa democracia" (50). É como se 30 anos depois do 25 de Abril chegássemos à conclusão de que muito falta fazer relativamente ao desenvolvimento, em áreas como a justiça, a educação, a ciência, a segurança social, a saúde... Neste sentido, como refere o historiador Luís Trindade, "a análise da actualidade portuguesa, hoje, constrói-se invariavelmente sobre uma comparaçáo com as expectativas da Revolução; no caso de Fantasia para dois coronéis e uma piscina é como se Mário de Carvalho chamasse a atenção para o falhanço do ideal de Abril" ${ }^{45}$, pelo menos no que à participação cívica diz respeito.

Mas falhou a revolução? "Não posso dizer-lhe isso porque me recordo de como era o país" ${ }^{\text {" }}$, contudo o isolamento proporcionado pela caravana atesta bem o descomprometimento político provocado pelo desencanto pós-revolucionário.

Cabe à literatura o papel de "organizar o mundo" e porventura "de conseguir o riso e a gargalhada", através da ironia e da paródia de textos de autores clássicos, gregos e latinos. "Nós, por vezes, pensamos que estas coisas dos Romanos não têm importância nenhuma e que são coisas antigas, velhas. Mas não. Nós estamos a falar em latim, estamos a falar uma língua latina, porque os romanos estiveram cá e deixaram-nos esta herança.

bombeiros", além de "uma coruja ao ombro, muito resplandecente" (156), o seu animal favorito. A lança e a égide eram as suas outras insígnias. Cf. Grimal, s.u. 'Atena' e 'Palas'.

45 Trindade 2004: 20-31.

46 Luís, Sara Belo, entrevista a Mário de Carvalho “Que raio de país é este?”:Visão 561, 04/10/2003: 174178. Entrevista de Sara Belo Luís. 
Os autores desse tempo ainda nos estáo a falar. Somos o mesmo homem. Não há grandes diferenças entre o homem daquele tempo e o homem de hoje. Por isso é que conseguimos ler as obras do passado e elas nos podem entusiasmar tanto" ${ }^{\prime \prime}$.

Tirar do passado o proveito e o exemplo, para evitar cometer os mesmos erros dos antepassados, parece ser a liçáo maior a tirar desta Fantasia. Afinal, voltando ao passado talvez se possa "interrogar as raízes de um presente em deriva de valores e certezas" ${ }^{\prime \prime 4}$. Hoje como ontem...

47 Mário de Carvalho, em entrevista a Ana Sousa Dias no programa "Por outro lado": A Dois 29/03/2004.

48 Júdice 1997: 97-98. 


\section{Bibliografia Geral}


(Página deixada propositadamente em branco) 


\section{Ediçôes de Mário de Carvalho}

(21990), Contos da sétima esfera. Lisboa, Caminho.

(1991), Quatrocentos mil sestércios. Lisboa, Caminho.

(71991), Casos do beco das sardinheiras, Lisboa, Caminho.

(31993), A Paixão do Conde de Fróis. Lisboa, Caminho.

(1996), Os Alferes. Lisboa, Caminho.

( $\left.{ }^{3} 1996\right)$, O livro grande de Tebas, Navio e Mariana. Lisboa, Caminho.

(1997), Um deus passeando pela brisa da tarde, Lisboa, Caminho.

$\left({ }^{3} 1997\right)$, Fabulário. Lisboa, Caminho.

(52003), Era bom se trocássemos umas ideias sobre o assunto. Lisboa, Caminho.

(32004), Fantasia para dois Coronéis e uma Piscina. Lisboa, Caminho.

('2006), A inaudita guerra da Avenida Gago Coutinho. Lisboa, Caminho.

(2008), A sala magenta. Lisboa. Caminho.

(2010), A Arte de Morrer Longe. Lisboa, Caminho.

\section{Estudos}

Adorno, T. W. ('1983), "Posição do narrador no romance contemporâneo". In: Benjamin, Honkheimer, Adorno, Habermas. Trad. port. José L. Grünnewald et alii. São Paulo, Abril Cultural: 269-273.

Albaladejo, T. (1986), Teoría de los mundos posibiles y macroestructura narrativa. Alicante, Universidade de Alicante.

Albaladejo, T. (1992), Semántica de la narración: la ficción realista. Madrid, Taurus.

Albérès, R. M. (1972), Métamorphoses du roman. Paris, Albin Michel.

Almeida, J. F. (1997), Bíblia Sagrada. Rio de Janeiro, Fecomex (Ed. Revisada e corrigida).

Alves, C. C. (2010) "Vestígios do trágico em Mário de Carvalho”. Navegaçôes 3. 1: 53-58.

Anacleto, M. T. (1996), “(Sub)versions du "cliché” romanesque au XVII siècle: le "roman bourgeois" de Furetière”, Confluências 14: 97-109.

Angelini, P. R. K. (2011) "Recensão de Carvalho, M. A arte de morrer longe. Lisboa, Caminho, 2010. 128p.”. Navegaçōes 4. 1: 131-133.

Arnaut, A. P. (2001), "Donas e donzelas n'a Demanda do Santo Graal”, Santa Barbara Portuguese Studies. Califórnia, n. 5: 29-71. 
Aristófanes (21989), A Paz. Tradução de Silva. M. F. Coimbra, Instituto Nacional de Investigação Científica.

Aristófanes (2006), As Aves. Tradução de Silva, M. F. Lisboa, Edições 70.

Aristóteles (1986), Poética. Tradução de E. Sousa. Lisboa, Fundação Gulbenkian.

Arnaut, A. P. (2002), Post-Modernismo no romance português contemporâneo. Fios de Ariadnemáscaras de Proteu. Coimbra, Almedina.

Assis, A. K. T. (2008), Arquimedes, o centro de gravidade e a lei da alavanca. Montreal, Apeiron Montral.

Auerbach, E (1976), Mimesis (A representação da realidade na literatura ocidental). São Paulo, Perspetiva [1 $1^{\text {a }}$ ed., 1946].

Aurélio, Marco (1971), Pensamentos. Versão de João Maia. Lisboa, Editorial Verbo.

Bakhtine, M. (1970), La Poétique de Dostoievsky. Paris, Éd. du Seuil.

Bakhtine, M. (1981), Dialogic imagination: four essays. Austin, University of Texas Press.

Bakthine, M. (1981), Problemas da poética de Dostoievski. Trad. port. Paulo Bezerra. Rio de Janeiro, Ed. Forense-Universitária.

Benjamin, W. (1985), "Sobre o conceito de História. Tradução de Sérgio Paulo Rouanet”. In: Obras escolhidas. Magia e técnica, arte e política. São Paulo, Editora Brasiliense: 222-232.

Bessière, J. (2010), Le roman contemporain ou la problemacité du monde. Paris, PUF.

Beye, C. R. (1964), "Homeric battle narrative and catalogues", Harvard Studies in Classical Philology 68: 345-373.

Bergson, H. (2001), O riso: ensaio sobre a significação da comicidade. Trad. port. Ivone C. Benedetti. São Paulo, Martins Fontes.

Bhabha, H. K. (1998), O local da cultura. Belo Horizonte, Editora UFMG.

Bianchet, S. B. (2004), Petrônio. Satyricon. Edição bilíngüe. Belo Horizonte, Crisálida.

Bougnoux, D. (1991), "Le principe d'identification”. In Personnage et Histoire Littéraire. Toulouse, Presses Universitaires du Mirail: 187-195.

Brandão, J. L. (2001), A poética do Hipocentauro: Literatura, sociedade e discurso ficcional em Luciano de Samósata. Belo Horizonte, Ed. UFMG.

Brasete, M. F. (2003), “A crítica às mulheres no fr. 7 de Semónides de Amorgos”. In: Mora, C. M. (ed.), Sátira, Paródia e Caricatura: da Antiguidade aos nossos dias. Aveiro, Universidade de Aveiro: 39-56.

Brauner, E. F. (2009), “" Era bom que trocássemos umas ideias sobre o assunto”: ironia de um narrador e discussão do romance", Revista Electrónica de critica e teoria de literaturas. Dossiê: o romance português e o mundo contemporâneo 5. 2. Porto Alegre: 1-9.

Buescu, H. (1995), A Lua, a Literatura e o Mundo. Lisboa, Cosmos. 
Buescu, M. L. C. (1979), Aspectos da herança clássica na cultura portuguesa. Lisboa, Instituto de Cultura Portuguesa.

Camôes, L. (1979), Os Lusíadas. Prefácio de Hernâni Cidade. São Paulo, Abril Cultural.

Carcopino, J. (1993), La vida cotidiana en Roma en el apogeo del imperio, trad. esp. Madrid, Ediciones Temas de Hoy.

Cardoso Bernardes, J. A. (1988), O Bucolismo Português. A égloga do Renascimento e do maneirismo. Coimbra, Livraria Almedina.

Carvalho, M., (2003), "Mário de Carvalho: crónica do aturdimento". JL - Jornal de Letras, Artes e Ideias 864, 12/11: 12.

Ceia, C. (2007), A Construção do romance (Ensaios de literatura comparada no campo dos estudos anglo-portugueses). Coimbra, Almedina.

Chevalier, J., Gheerbrant, A. (1994), Dicionário dos Símbolos, trad. port., Lisboa, Editorial Teorema.

Colaço, J. (1995), “Mário de Carvalho”, Biblos. Enciclopédia verbo, I, s.u.

Compagnon, A. (2001), O demônio da teoria: Literatura e senso comum. Belo Horizonte, Editora UFMG.

Constâncio, N. (2007), Ruinas e incertezas em "Um Deus passeando pela brisa da tarde”, de Mário de Carvalho. Lisboa, Edições Colibri.

Costa, L. S. (1995), “Era Bom que Trocássemos Umas Ideias Sobre O Assunto, de Mário de Carvalho. A Arquitectura, A Violência”. In: Público/Leituras, 11 de Novembro:10.

Cotrim, J. P. (1996), Entrevista a Mário de Carvalho: "Alguma coisa me perturba”. Ler/Livros e Leitores 34: 45.

Cotrim, J.P. (1996), "Mário de Carvalho. O Mistério da Literatura”, entrevista ao autor. LER 34, Primavera.

Cristóbal, V. (1992), "Búsqueda de campo, hastío de ciudad. Pasión antigua y contemporánea”. In: Guzmán, A. et alii (ed.), Aspectos modernos de la Antigüedad y su aprovechamiento didáctico. Madrid, Ediciones Clásicas: 131-143.

Davison, M. (1976), "The thematic use of ekphrasis in the ancient novel”, in Erotica antiqua. Acta of the International Conference on the Ancient Novel. Bangor, ICAN: 32-33.

Devereux, G. (1975), Dreams in Greek tragedy. Oxford, Basil Blackwell.

Dijksterhuis, E. J. (1987), Archimedes. Translated by C. Dikshoorn. Princeton University Press.

Diogo, A. A. L. (1997), "Exórdio". In: Biblos- Enciclopédia Verbo das Literaturas de Lingua Portuguesa. Lisboa, São Paulo, Verbo.

D’Onofrio, S. (1978), Poema e Narrativa: estruturas. São Paulo, Duas Cidades. 
Duncan, T.S. (1935), “The deus ex machina in Greek Tragedy”. Philological Quarterly 14: $126-141$.

Dunn, F. M. (1985), Euripidian Endings: a Study of the Choral Exit, the Action, the Concluding Prophecy and the Deus ex Machina. Yale University: 111-167.

Eco, U. (1979), Leitura do Texto Literário. Lector in Fabula. Trad. Mário Brito. Lisboa, Presença.

Entrevista com Mário de Carvalho http://www.homemmag.pt/pt/index.php/arte-e-literatura/arquivo-arte-literatura/87-luisa-costa-gomes-entrevista-mario-de-carvalho

Ernout, A. ( $\left.{ }^{11} 1993\right)$, Pétrone. Le Satyricon. Paris, Les Belles Lettres.

Ernout A, Meillet, A. ( $\left.{ }^{4} 1967\right)$, Dictionnaire etymologique de la langue latine: histoire des mots. Paris, Librairie C. Klincksieck.

Errandonea, I. (1954), Diccionario del mundo clásico. Barcelona, Editorial Labor.

Eschilo ( $\left.{ }^{4} 2000\right)$ I sette contro Tebe. Con testo a fronte. Introd. Umberto Albini. Trad. Ezio Savino. Milano, Garzanti Editore.

Feijóo, B. (1998), Um Não Sei Quê. Lisboa, Vega [1746].

Ferreira, C. (2003), “Mário de Carvalho. A arte de bem iludir o leitor”. In: Rodapé: 45-51.

Ferreira, P. S. (1999), “A paródia e as suas implicações didácticas”. In: Torrão, J. M. N. (ed.), III Colóquio Clássico - Actas. Aveiro, Universidade de Aveiro: 113-137.

Ferreira, P. S. (2000), Os elementos paródicos no Satyricon de Petrónio e o seu significado. Lisboa, Colibri.

Ferreira, P. S. (2003), “Paródia ou paródias?”. In: Mora, C. M. (ed.), Sátira, Paródia e caricatura: da Antiguidade aos nossos dias. Aveiro, Universidade de Aveiro: 279-300.

Fialho, M. C. (1992), Luz e trevas no teatro de Sófocles. Coimbra, Instituto Nacional de Investigação Científica.

Figueiredo, M. N. (2006), "Com humana crueldade se tece um conto. A propósito de Homenagem ao Papagaio Verde”. In: Santos, G. (ed.) Jorge de Sena: Ressonâncias e Cinqüenta Poemas. Rio de Janeiro, 7Letras.

Fowler, D. P. ((1991), "Narrate and describe: the problem of ecphrasis", Journal of Rhetorical Studies 81: 25-35.

Frow, J. (1986), “Spectacle Binding: On Character”. Poetics Today 7. 2: 227-250.

Gaffiot, F. (1934), Dictionnarie Illustré Latin-Français. Paris, Librairie Hachette.

Garrett, A. (1973), Viagens na minha Terra. Rio de Janeiro, Editora Três.

Genette, G. (1972), Figures III. Paris, Ed. du Seuil.

Gennete, G. (1997), L'Cuvre de l'Art. La Relation Esthétique, II. Paris, Ed. du Seuil.

Genette, G. (2004), Métalepse. Paris, Ed. du Seuil.

Gomes da Torre, M. (1992), “Acerca da tradução da metáfora”. Linguas e Literaturas 9: 209-226. 
Grimal, P. (s/d), Dicionário de Mitologia Grega e Romana. Lisboa.

Guillén, J. (1977), Vrbs Roma - vida e costumbres de los romanos, vol. I: La vida privada. Salamanca, Ediciones Sígueme.

Guthrie, W. K. C. (1976), Les Sophistes. Paris, Payot.

Halliwell, S. (1968), Aristotle's Poetics. Chicago and London.

Hamon, P. (1976), “O que é a descrição?”. In: Seixo, M. A. (ed.), Categorias da narrativa. Lisboa, Arcádia: 61-83.

Hardwick, L. (2003), Reception Studies. Greece and Rome. New Surveys in the Classics. Oxford, Oxford University Press. [recensão do livro por Martin M. Winkler, in Bryan Mawr Classical Review 2004].

Heródoto. (2002), Histórias. Livro I. Tradução de Ferreira, J. R., Silva, M. F. Lisboa, Ediçóes 70. Heródoto (1997), Histórias. Livro III. Tradução de Silva, M. F., Abranches, C. Lisboa, Ediçóes 70. Heródoto (2000), Abranches, C., Histórias. Livro IV. Tradução de Silva, M. F., Abranches, Lisboa, Edições 70.

Homero (2003), Odisseia. Tradução de Frederico Lourenço. Lisboa, Livros Cotovia.

Homero (2005), Ilíada. Tradução de Frederico Lourenço. Lisboa, Livros Cotovia.

Hoorn, J. F., and Konijn, E. A. (2003), "Perceiving and experiencing fictional characters: An integrative account”. Japanese Psychological Research 45. 4: 250-268.

Horácio (1975), Arte Poética. Tradução de R. M. R. Fernandes. Lisboa, Clássica Editora.

Hutcheon, L. (1977), “Modes et formes du narcisisme littéraire”. Poétique 29: 90-106.

Hutcheon, L. (1984), Narcissistic Narrative. The Metafictional Paradox. New York and London, Methuen.

Hutcheon, L. (1985), A Theory of Parody. The Teachings of Twentieth Century Art Forms. New York \& London, Methuen; (1989), Uma teoria da paródia, trad. port. Lisboa, Ediçóes 70.

Hutcheon, L. (1988), A poetics of Postmodernism. History, Theory, Fiction. New York/London, Routledge; (1991), Poética do Pós-Modernismo. Trad. Ricardo Cruz. Rio de Janeiro, Imago.

Hutcheon, L. (2000), Teoria e Política da Ironia. Trad. port. Julio Jeha. Belo Horizonte, Editora UFMG.

Immerwahr, H. R. (1966), Form and thought in Herodotus. University of North Carolina.

Izaac, H. J. ( ${ }^{3} 1969$, 1973), Martial. Épigrammes, I-II. Paris, Les Belles Lettres.

Jauss, H. R. (1986), Experiencia y Hermeneutica Literaria. Ensayos en el campo de la experiencia estétca. Madrid, Taurus, [1977].

Jenny, L. (1979), "A estratégia da forma”, Poétique. Revista de teoria e análise literárias. Trad. port. Clara C. Rocha. Coimbra, Almedina: 5- 49. 
Jerome, K. J. , “Three men on the Brummel'. In: http://www.gutenberg.org/catalog/world/ readfilefk_files $=2061881$

Jourdan, P. (1996), "Paul Valéry chasseur de perroquets", Confluências 14: 51-59.

Júdice, N. (1997), Viagem por um século de Literatura Portuguesa. Lisboa, Relógio d'Água.

Julien, Y. (1998), Aule-Gelle. Les nuits attiques, IV. Paris, Les Belles Lettres.

Jurado, F. G. (1999), "Apuntes para una historia prohibida de la literatura latina en el siglo XX: La voz de los lectores no académicos”. In: Morán, M. C. A.; Iglesias Montiel, R. M. (eds.), Contemporaneidad de los clásicos en el umbral deI tercer milenio. Actas deI Congreso Internacional Contemporaneidad de los clásicos: La tradición greco-latina ante el siglo XXI. La Habana, Universidad de Murcia: 77-85.

Kerferd, G. B. (2003), O movimento sofista. Trad. port. Margarida Oliva. São Paulo, Ediçôes Loyola.

Kirk, D. M. (1960), The digression, its use in prose fiction from the Greek romance through the eighteenth century. Stanford University.

Kristeva, J. (1974ª), Introdução à semanálise. São Paulo, Perspectiva.

Kuester, M. (1992), Framing Truths - Parodic Structures in Contemporary English-Canadian Historical Novels. Toronto/London, Toronto University Press.

Lausberg, H. (1963), Elementos de retórica literária. Trad. port. Raul M. Rosado Fernandes, Lisboa, Gulbenkian.

Leão, D. F. (1996), “Trimalquião: a humanitas de um novo-rico”. Humanitas 48: 161-182.

Leão, D. F. (1997), “Trimalquião à luz dos Caracteres de Teofrasto”. Humanitas 49: 147-167.

Leão, D. F. (1998), As Ironias da Fortuna. Sátira e Moralidade no Satyricon de Petrónio. Lisboa, Colibri.

Leão, D. F. (2004), “Zoilo e Trimalquião, duas variaçôes sobre o tema do novo-rico”. Humanitas 56: 191-208.

Leão, D. F. (2004a), “O Satyricon de Petrónio e a crise dos paradigmas tradicionais”. In: Nascimento, A. (ed.), Antiguidade Clássica: Que fazer com este património?. Lisboa, Centro de Estudos Clássicos: 233-242.

Leão, D. F. (2005), Petrónio. Satyricon. Lisboa, Cotovia.

Lepaludier, L (2002), Métatextualité et métafiction. Théorie et analyses, Presses Universitaires de Rennes, CRILA.

Levi, P. (1988), É isto um homem? Rio de Janeiro, Rocco.

Lévy, E. (1983), "Le théâtre et le rêve: le rêve dans le théâtre d'Eschyle", in Zehnacker, H. (ed.), Théatre et spectacles dans l'Antiquité. Actes du Colloque de Strasbourg. Leiden: 141-168.

Lopes, S. R. (2003), Literatura, Defesa do atrito. Lisboa, Copiart. 
Lourenço, E. ('1982), "Da literatura como interpretação de Portugal”. In O Labirinto da Saudade (Psicanálise Mitica do Destino Português). Lisboa, D. Quixote: 85-126.

Lourenço, F. (2003), Homero. Odisseia. Lisboa, Cotovia.

Luciano (1996), Uma história verídica. Tradução de C. Magueijo. Lisboa, Editorial Inquérito Limitada.

Lukács, G. (1989), Théorie du roman. Paris, Flammarion [1916].

"Na Lusitânia com Mário de Carvalho (História, paródia e ironia em Quatrocentos mil sestércios e Um deus passeando pela brisa da tarde)". In Veredas 5 (2002) 211-224.

Macedo, A. G. (2008), Narrando o pós-moderno: reescritas, revisôes, adaptaçôes. Braga Universidade do Minho.

Machado, J. P. (1995), Dicionário etimológico da Língua Portuguesa. Lisboa, Livros Horizonte.

Malina D. (2002), Breaking the frame: metalepsis and the construction of the subject. Columbus, Ohio State UP.

Margolin, U. (2005), “Character”. In: Herman, D., Jahn M., Ryan, M.-L. (eds.), Routledge Enciclopedia of Narrative Theory. London/New York, Routledge: 54-57.

Marinho, M. F. (1996), "O sentido da história em Mário de Carvalho", Revista da Faculdade de Letras. Linguas e Literaturas: 257-267.

Marinho, M. F. (2010), "À la recheche de l'identité perdue. Essai sur la crise d'identité dans le roman portugais contemporain”. In: Besse, M. G. \& Ralle, M. (eds.), Les Grands Récits: Miroirs Brisés? Paris, Índigo:186-198.

Martin, F. (1987), Les mots latins. Paris, Hachette.

Martins, J. C. O. (2011), "Mário de Carvalho e a reflexão metaficcional sobre o futuro do romance”. Diacrítica. Dossiê Literatura e Religiāo 25/3: 23-44.

Martins, J. C. O. (2011), “Pensar Portugal - ironia, paródia e desencanto: Mário de Cavalho e o retrato melancólico de um país". In: Carvalho da Silva, J. A., Martins, J. C. O., Gonçalves, M. (eds.), Pensar a Literatura no Séc. XXI. Braga, Univ. Católica Portuguesa: 463-478.

Martins, J. C. O. (s.d.), "La barbarie de l'ignorance dans la culture postmoderne et la fiction de Mário de Carvalho". In: De l'Extrême: pratiques du contemporain dans les mondes ibériques et ibéro-américains, Paris, CRIMIC [em publicação].

Martins, M. F. (1983), Sombras e transparências da literature. Lisboa, INCM.

Martins, Maria João (2003), "Mário de Carvalho: crónica de um aturdimento" [entrevista], JL - Jornal de Letras, Artes e Ideias, no 864, 12 novembro, p. 12.

Mead, G. (1990), “The Representation of Fictional Character”. Style 24. 3: 440.

Medeiros, W. (1997), "Do desencanto à alegria: o Satyricon de Petrónio e o Satyricon de Fellini”. Humanitas 49: 169-175. 
Melanda, P. C. O. (2001), Pela mão de Clio. A reescrita da História em Mário de Carvalho. Aveiro. 38. Dissertação de Mestrado em Estudos Portugueses, apresentada à Universidade de Aveiro. Exemplar em CDRom.

Melero Bellido, A. (2001), "La utopia cómica o los límites de la democracia”, Cuadernos de Literatura Griega y Latina 3: 7-25.

Melero Bellido, A. (2004), "La lengua de la utopia". In: López Eire, A., Guerrera, A. R. (Eds.). Registros Lingüísticos en las lenguas clásicas. Salamanca, Ediciones Universidad Salamanca: 149-172.

Mendes, A. M. G. (1999), "Cultura clássica em Um Deus Passeando pela brisa da tarde de Mário de Carvalho”, III Colóquio Clássico - Actas, Aveiro: 347-363.

Mendes, A. M. G. (2005), “Trimalquião, os coronéis e a piscina: retrato impiedoso de um país em crise”. Ágora. Estudos Clássicos em Debate. Aveiro 7: 129-150.

Mendes, J. P. (1997), Construção e Arte das Bucólicas de Virgílio. Coimbra, Almedina.

Mendonça, F. (1997), “A Paixão do Conde Fróis”. Colóquio/Letras 99. Setembro-Outubro.

Mexia, P. (2005), “O Manuel Germano”. Diário de Notícias. Artes, 17 de Junho: http:// dn.sapo.pt/2005/06/17/artes/o_manuel_germano.html

Moisés, M. ('1973), A criação literária: introdução à Problemática da Literatura. São Paulo, Melhoramentos.

Mora, C. M. (2003), “A outra resposta de Tirésias”. In: Mora, C. M. (ed.), Sátira, Paródia e caricatura: da Antiguidade aos nossos dias. Aveiro, Universidade de Aveiro: 7-13.

Morais e Silva, A. (1953), Grande Dicionário da Lingua Portuguesa. Lisboa, Confluência.

Mourão, J. A. (1998), "Posfácio”, a Feijóo, Benito - Um Não Sei Quê. Lisboa, Vega.

Nickel, R. (1999), “Lucian's True Story: impressions of a fancy voyage”, Euphrosyne 27: 249-257.

Niederauer, S. (2008), "Era bom que trocássemos umas ideias sobre o assunto ou $\mathrm{O}$ simulacro da narrativa na pós-modernidade”. Letras de Hoje 43. 4: 83-88.

Oliveira, B. S. (1997), Eurípides. Hipólito. Brasília, Editora UNB.

Onelley, G. B. (2004), “A resistência da nau: cidade na luta pelo poder”. Calíope 12: 33-42.

Otte, G. (1996), "Rememoração e citação em Walter Benjamin". Revista de Estudos de Literatura 4. Belo Horizonte, Centro de Estudos Literários (CEL), Faculdade de Letras da UFMG: 211-223.

Pereira, E. (2003), "Viagens na minha terra: ciladas da representação". Revista do Centro de Estudos Portugueses 23 n. 32: 61-68.

Pereira, S. M. (2008), “Poética dos sonhos e das visōes em estado de vigília - I”, Humanitas 60: 11-28.

Pereira, S. M. (2009), "Poética dos sonhos e das visōes em estado de vigília - II”, Humanitas 61: 5-18.

Perelman, C. O. (1993), O Império Retórico: Retórica e Argumentação. Tradução de Fernando Trindade e Rui Alexandre Grácio. Porto, Ediçóes Asa. 
Perrin-Naffakh. A.-M. (1996), "Le langage cliché: aveu d'usure ou pouvoir d'écho". Confluências 14: 7-14.

Perrone-Moisés, L. (1979), “A intertextualidade crítica”. Poétique. Revista de teoria e análise literárias. Trad. port. Clara C. Rocha. Coimbra, Almedina: 209-230.

Pimentel, C. S. (2001), "O latim nas literaturas portuguesa e francesa: instrumentos, métodos e agentes de ensino”, Ágora, Estudos Clássicos em Debate 3: 183-185.

Piwnik, M.-H. (1998), "Mário de Carvalho: crónica de um desfecho anunciado", Veredas 1, Porto: 317-325.

Piwnik, M.-H. (2004), “De Sienkiewicz a Mário de Carvalho: Duas construções da História”. In: Literatura e História. Actas do Colóquio Internacional, Porto, vol. II: 139-144.

Platão ( $\left.{ }^{12} 2010\right)$, República. Trad. Maria Helena da Rocha Pereira. Lisboa, Fundação Calouste Gulbenkian.

Préchac, F. (1987), Sénèque. Lettres a Lucilius, II. Paris, Les Belles Lettres.

Queirós, E. de (s./d.), Os Maias. Lisboa, Livros do Brasil.

Queirós, E. de (2000), O Crime do Padre Amaro. Ed. crítica de Carlos Reis e M. Rosário Cunha. Lisboa, IN-CM.

Rabaté, E. (1996), "Henri Michaux et le cliché: résistance et fascination”. Confluências 14: 61-75.

Raimond, M. (1989), Le Roman. Paris, Armand Colin.

Reis, C. (1996), "Mário de Carvalho. Incitação ao romance”. Jornal de Letras 28 Agosto: 22-23.

Reis, C. (1997), "Fábula”. In: Biblos-Enciclopédia Verbo das Literaturas de Lingua Portuguesa. Lisboa, São Paulo, Verbo: 462-463.

Reis, C. (2005), História crítica da literatura portuguesa, vol. IX (Do neorrealismo ao postmodernismo). Lisboa, Verbo: 287-318.

Reis, C., Macário Lopes, A. C. (72007), Dicionário de narratologia. Coimbra, Almedina.

Ricoeur, P. (1983), Temps et Récit. T.I. Paris, Ed. du Seuil.

Rio Torto, G. M. (1996), "Linguagem e clichê", Confluências 14: 159-175.

Robilliard, M.-A. (2002), Água em pena de pato de Mário de Carvalho. Um teatro do desencanto. Trad. port. Manuel Ruas. Lisboa, Editorial Caminho.

Rocha Pereira, M. H. (1955), Concepçōes Helénicas de felicidade no além: de Homero a Platão. Coimbra, Maranus.

Rocha Pereira, M. H. (1980), Poesia Grega Arcaica. Coimbra, Instituto de Estudos Clássicos.

Rocha Pereira, M. H. (1984), Estudos de História da Cultura Clássica, vol. II (Cultura Romana). Lisboa, Fundação Calouste Gulbenkian.

Rocha Pereira, M. H. ('1994), Romana - Antologia da Cultura Latina. Coimbra, Universidade de Coimbra. 
Rocha Pereira, M. H. ( $\left.{ }^{10} 2006\right)$, História da Cultura Clássica, I (Cultura Grega). Lisboa, Fundação Calouste Gulbenkian.

Rodrigues, L. G. (2005), “A Radioestesia”. In http://rprecision.logspot.com/2005/06/radiestesia.html Rose, M. A. (1979), Parody and meta-fiction. London, Croom Helm.

Sant'Anna, A. R. ('1985), Parodia, paráfrase \& cia. São Paulo, Ática.

Santos, R. B. (2009), Aspectos da Herança Clássica em Mário de Carvalho. Belo Horizonte, Faculdade de Letras da UFMG, 2009. [versão policopiada].

Saramago, J. (1989), História do Cerco de Lisboa. Lisboa, Caminho.

Saramago, J. (1990), "História e Ficção”. Jornal de Letras, Artes e Ideias, 6 de Março.

Schaeffer, J. M. (1992), L'art de l'àge moderne. L'esthétique et la philosophie de l'art du XVIIIème siècle à nos jours. Paris, Gallimard.

Schmidt, W. (1963), Der Deus Ex Machina bei Euripides. Tübingen University.

Schwartz, J. (1981), Murilo Rubião: A poética do Uroboro. São Paulo, Editora Ática.

Scodel, R. (1999), Credible impossibilities. Conventions and strategies of verisimilitude in Homer and Greek tragedy. University of Michigan Press.

Sedlmayer, S., "Sinais de fogo, aviso de incêndio: ideias estéticas, históricas e literárias em Jorge de Sena e Walter Benjamin”. In: Revista Literatrua e Autoritarismo. Dossiê Walter Benjamin e a Literatura brasileira. Santa Maria, Universidade Federal de Santa Maria/ RS. Disponível em http://w3.ufsm.br/grpesqla/revista/dossie05/art_02.php

Seel, M. (1992), "Le langage de l'art est muet". In: Bouchindhomme, Ch., Rochlitz, R. (eds.), L'art Sans Compas. Redéfinitions de l'Esthétique. Paris, Éd. du Cerf.

Segurado e Campos, J. A. (1991), Cartas a Lucílio, Lisboa, Fundação Calouste Gulbenkian.

Seixo, M. A. (1995), "Mário de Carvalho. Romance, Humanismo e BD”, JL - Jornal de Letras, Artes e Ideias, 12. 4: 24-25.

Sena, J. http://www.letras.ufrj.br/lerjorgedesena/port/antologia/ficcao-e-teatro/texto.php?id=319

Sequeira, M. G. R. (1996), Aproximação a uma Leitura do Risivel em A Paixão do Conde de Fróis. Tese de Mestrado apresentada à Faculdade de Letras da Universidade do Porto (dact.).

Settis, S. (2006), El futuro de lo 'clásico'. Traducción de Andrés Soria Olmedo. Madrid, Abada Editores.

Silva, M. F. (1987), Critica do teatro na comédia antiga. Coimbra, INIC.

Silva, M. F. (2005), Ensaios sobre Euripides. Lisboa, Cotovia.

Silva, M. F. (2007), "A porta na comédia de Aristófanes: uma entrada para a utopia”. In: Ensaios sobre Aristófanes. Lisboa, Cotovia: 257-274. 
Silva, M. F. (2008), "Mensagens, cartas e livros no teatro grego antigo", in Matos, M. C. (ed.), Helénicos. Estudos em homenagem do Prof. Jean-Pierre Vernant (1914-2007). Lisboa, Ediçôes Távola Redonda: 227-260.

Silva, M. F. (2009), Utopias e distopias. Coimbra, Imprensa da Universidade.

Silvestre, O. M. (1998), "Mário de Carvalho: Revolução e Contra-revolução ou um passo atrás e dois à frente”. Colóquio/Letras 147/148: 209-229.

Silvestre, O. e Diogo, A. L. (1998), "Entrevista a Mário de Carvalho", in <http://www. ciberkiosk.pt>, arquivo, $\mathrm{n}^{\circ} 1$ (15 pp.).

Simões, M. J. (2006), “Atrevidas e desbordantes: as personagens em Mário de Carvalho”. In Figuras da Fiç̧ão. Coimbra, Centro de Literatura Portuguesa: 79-92.

Spivak, G. Ch. ('2003), “Can the subaltern speak?” In: Asheroft, B., Griffith, G., Tiffin, H. (eds.), The post-colonial studies reader. New York, Routledge.

Spivak, G. Ch. (1998), "Puede hablar elsujeto subalterno?”. Orbis Tertius 3. 6: 1-44.

Sterne, L. (1860), The Works of Lawrence Sterne. London, Henry Bohn.

Thomasson, A. (2003), "Fictional Characters and Literary Practices". British Journal of Aesthetics 43. 2, April:138-157.

Todorov, T. (1999), O homem desenraizado. Trad. Christina Cabo. Rio de Janeiro, Record.

Torrão, J. M. N. (ed.) (1999), III Colóquio Clássico. Aveiro, Universidade de Aveiro.

Tosi, R. (2000), Dizionario delle sentenze latine e greche. Milano, Biblioteca Universale Rizzoli.

Trindade, L. (2004), “Os excessos de Abril”, História 65: 20-31.

Valente, A. M. (2004), Aristóteles. Poética. Lisboa, Gulbenkian.

Várzeas, M. (2001), Silêncios no teatro de Sófocles, Lisboa, Cosmos.

Villeneuve, F. (1970), Horace. Odes et Epodes, I. Paris, Les Belles Lettres.

Xavier, L. G. (2007), O discurso da ironia. Lisboa, Novo Imbondeiro.

Walton, K. (1990), Mimesis as Make-Believe: On the Foundations of the Representational Arts. Cambridge Mass., Havard University Press.

Waugh, P. (2003), Metafiction. The Theory and Practice of Self-Conscious Fiction. London \& New York, Routledge [1984].

Wesseling, E. (1991), Writing History as a Prophet. Postmodernist Innovations of the Historical Novel. Amsterdam/Philadelphia, John Benjamins.

Wolff, F. (2004), “Quem é bárbaro?”. In: Novaes, A. (ed.), Civilização e Bárbarie. São Paulo, Companhia das Letras: 19-43.

Woods, J. (1974), The Logic of Fiction. Paris, Mouton; (2010), A Mecânica da fiç̧âo. Lisboa: Quetzal. Zagajewski, A. (2003), En la belleza ajena, trad. esp. A. E. Diaz-Pintado Hilario, Valencia, Pre-Textos. 